\section{A NONLINEAR FINITE ELEMENT ANALYSIS OF PRECAST INDUSTRIALISED BUILDING SYSTEM BEAM UNDER FLEXURAL TEST}

\author{
Chun-Chieh Yipa*, Jing-Ying Wong ${ }^{b}$, Ka-Wai Hora
}

aDepartment of Civil Engineering, Universiti Tunku Abdul Rahman, Bandar Sungai Long, 43000, Cheras, Kajang, Selangor, Malaysia bDepartment of Civil Engineering, University of Nottingham Malaysia Campus, 43500, Semenyih, Selangor, Malaysia
Article history

Received

8 February 2018

Received in revised form

14 February 2019

Accepted

19 February 2019

Published online

18 April 2019

*Corresponding author yipcc@utar.edu.my

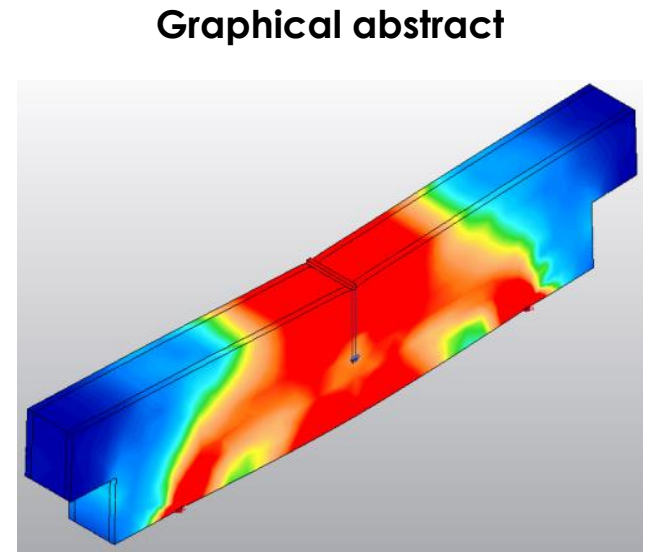

\begin{abstract}
Software simulation enables design engineers to have a better picture of possible structural failure behaviour and determine the accuracy of a design before the actual structural component is fabricated. Finite element analysis is used to simulate the behaviour of the reinforced concrete beam under the flexural test. During the flexural test, results are recorded for both simulation and experimental tests. By comparing the results, beam displacement, crack patterns, and failure modes can be studied with better accuracy. The accuracy percentage for yield load and ultimate load between the two tests results were $94.12 \%$ and $95.79 \%$, respectively, whereas the accuracy percentage for elastic gradient before the yielding stage was $81.08 \%$. The behaviour between simulation and laboratory models described is based on crack pattern and failure mode. The progression of von Mises (VM) stresses highlighted the critical areas of the reinforced concrete beam and correlation between the experimental specimen, in terms of flexural cracks, shear cracks, yielding of tension reinforcement, and the crushing of concrete due to compressive stress. This paper concludes that simulation can achieve a significant accuracy in terms of loads and failure behaviour compared to the experimental model.
\end{abstract}

Keywords: Finite element analysis, precast reinforced concrete beam, flexural strength test, beam deflection, failure mode

\begin{abstract}
Abstrak
Perisian membolehkan jurutera reka bentuk mempunyai gambaran yang lebih jelas tentang kemungkinan kegagalan struktur dan menentukan ketepatan reka bentuk sebelum komponen struktur sebenar dihasilkan. Analisis unsur terhingga telah digunakan untuk mensimulasikan tingkah laku rasuk konkrit bertetulang di bawah ujian lenturan. Semasa ujian lenturan, keputusan telah direkodkan untuk kedua-dua simulasi dan eksperimen. Dengan membandingkan keputusan, anjakan rasuk, corak retakan, dan cara kegagalan boleh dikaji untuk ketepatan yang lebih baik. Peratusan ketepatan untuk beban hasil dan beban muktamad untuk kedua-dua ujian adalah masing-masing $94.12 \%$ dan $95.79 \%$. Peratusan ketepatan untuk kecerunan anjal sebelum tahap perubahan adalah $81.08 \%$. Tingkah laku antara simulasi dan model makmal dihuraikan berdasarkan corak retakan dan cara kegagalan. Perkembangan tekanan von Mises (VM) menyerlahkan kawasan kritikal rasuk konkrit bertetulang dan hubungan antara specimen ujian, dari segi retak lenturan, retak ricih, perubahan tegangan tetulang, dan kehancuran konkrit akibat tekanan mampatan.
\end{abstract}


Kertas ini menyimpulkan bahawa simulasi dapat mencapai ketepatan yang ketara dari segi beban dan corak kegagalan apabila dibandingkan dengan model eksperimen.

Kata kunci: Simulasi, Rasuk konkrit bertetulang pratuang, ujian lenturan; pesongan rasuk, mod kegagalan

(C) 2019 Penerbit UTM Press. All rights reserved

\subsection{INTRODUCTION}

The term 'Industrialised Building System' (IBS) denotes a construction method of part of structure or a building where the structural components are prefabricated wholly or partially, and are massproduced off-site for fabrication and installation at construction sites. The IBS has different terms in different countries, namely industrialised construction, pre-assembly, off-site manufacturing, prefabrication, modern method of construction, and off-site construction [1]. Prefabricated steel structures such as hot rolled steel beams, universal columns, and trusses are some of the often-used IBS products in the construction world. By comparing precast concrete structures with conventional construction, precast system is more advantageous in terms of practicality, improved quality control, effective use of materials, easier administration of construction schedule, and cost reduction [2].

In the construction world, minimising unnecessary cost is key to a successful business. Countless resources have been wasted during construction due to incompetence, and lack of proper management [3]. By doing simulation in the design phase of a construction, time and cost for the construction can be greatly reduced. Hence, this paper aims to provide a sense of confidence for the engineering community in simulating the real-life behaviour of structural components. The objectives of this paper are to simulate the deformation, behaviour, and stress concentration of IBS reinforced concrete (RC) beam under flexural test, as close as possible to the laboratory test counterpart.

When conducting the simulation analysis and experimental test, some assumptions need to be made to simplify the variables in finding the modulus of rupture and flexural analysis [4].The bending theory, which has been found to produce accurate experimental results, is based on some simplified assumptions. Nevertheless, users have to understand the theory and limitation behind the software to achieve accurate simulation results. Listed below are the assumptions used for this paper [5]:

i. The material is a homogeneous, isotropic, elastic continuum, and has the same properties in tension and compression, especially for Young's Modulus of Elasticity.
However, this assumption is not generally valid, and is rarely satisfied in reality;

ii. The material obeys Hooke's law. For nonHookean and composite materials, the theory should be modified;

iii. The beam is initially straight and bends into a circular arc;

iv. The radius of curvature is large compared to the dimensions of the cross-section;

v. The transverse sections which were plane before bending, remain plane after bending;

vi. Effects of concentrated loads are neglected.

With current technological advancement, the finite element analysis (FEA) is one of the most common and appropriate method for computer solution of complex problems related to engineering and mathematical physics fields [6]. The FEA is often used in civil engineering (structural analysis and fluid flow), mechanical engineering (heat and mass transfer), nuclear engineering, biomedical engineering, and also problems with difficult geometries and material properties. Solutions of ordinary or partial differential equations is not enough to solve analytical mathematics when complex and intrinsic variables are in play, hence the FEA solution is much more suitable [7]. FEA works by predicting how the objects react when subjected to heat, forces, vibration, etc. by breaking the said object into thousands of elements. However, the simulation study for scaled IBS RC beam under flexural test is not readily available. Thus, this is an important research gap that needs to be filled. Many parameters such as the configuration and input data are needed to perform the simulation to compare with experimental model for accuracy.

There are many finite element software packages available for online purchase, which are able to perform complex differential equations. These software may differ from each other in terms of userfriendliness, accessibility, analysis time, functionality, or compatibility with other software such as AutoCAD [8]. ANSYS and Abaqus are commonly used in the engineering world to perform finite element analysis, while Autodesk Simulation Mechanical is the software that is used to run the simulation in this study. 


\subsection{METHODOLOGY}

\subsection{Material Properties}

Before accessing the simulation software, there are a few data that need to be extracted and processed from its experimental counterpart. Data such as the dimension of the IBS RC specimen need to be converted into an AutoCAD drawing, so that the file can be read by the simulation software. Important parameters such as compressive strength of the concrete mix and tensile strength of steel reinforcements are information required to be tested in the laboratory. Table 1 shows the material properties of the concrete at 28 days to fabricate the RC beam specimen. Table 2 shows the material properties for $1.5 \mathrm{~mm}$ diameter of galvanized iron steel bars shear links. Table 3 shows the material properties for $5 \mathrm{~mm}$ diameter of mild steel bar used for the main reinforcement bar. All the material properties shown in Tables 1-3 were used as parameters in conducting the FEA of IBS RC beam.

Table 1 Material properties of concrete at 28 days

\begin{tabular}{ll}
\hline \multicolumn{3}{c}{ Material Properties of Concrete } \\
\hline Average maximum compressive strength (MPa) & 33.18 \\
Average maximum splitting tensile strength (MPa) & 3.50 \\
Average modulus of elasticity (GPa) & 37.50 \\
\hline
\end{tabular}

Table 2 Material properties of $1.5 \mathrm{~mm}$ diameter steel bar

\begin{tabular}{ll}
\hline \multicolumn{2}{c}{ Material Properties of $\mathbf{1 . 5} \mathbf{~ m m}$ Reinforcing Steel } \\
\hline Diameter (mm) & 1.50 \\
Average yielding stress (MPa) & 442.00 \\
Average ultimate stress (MPa) & 541.30 \\
Average maximum strain (mm/mm) & 0.22 \\
Average modulus of elasticity (GPa) & 242.50 \\
\hline
\end{tabular}

Table 3 Material properties of $5 \mathrm{~mm}$ diameter steel bar

\begin{tabular}{ll}
\hline \multicolumn{2}{c}{ Material Properties of $\mathbf{5} \mathbf{~ m m}$ Reinforcing Steel } \\
\hline Diameter (mm) & 5.00 \\
Average yielding stress (MPa) & 438.30 \\
Average ultimate stress (MPa) & 578.10 \\
Average maximum strain (mm/mm) & 0.35 \\
Average modulus of elasticity (GPa) & 166.40 \\
\hline
\end{tabular}

\subsection{Model Specification}

The IBS RC beam was drawn with the exact dimension of the reinforced concrete beam used in the experimental counterpart. The model was drawn in the Autodesk AutoCAD with the units of millimetre as shown in Figures 1 and 2, representing the 3D view and the front view, respectively. The green part in the drawing represents the concrete beam, while the red parts represent the load-applying block and two specimen support blocks. These red blocks had a dimension of $40 \mathrm{~mm}$ width $\times 3 \mathrm{~mm}$ length $\times 3 \mathrm{~mm}$ height to give a uniform load along the width of the beam. Figure 3 shows the reinforcing steel in the concrete beam, which included two main steel bars with a diameter of $5 \mathrm{~mm}$, and 16 shear links with 1.5 $\mathrm{mm}$ in diameter with a spacing of $20 \mathrm{~mm}$. The drawing of the beam was then exported in an IGES file type.

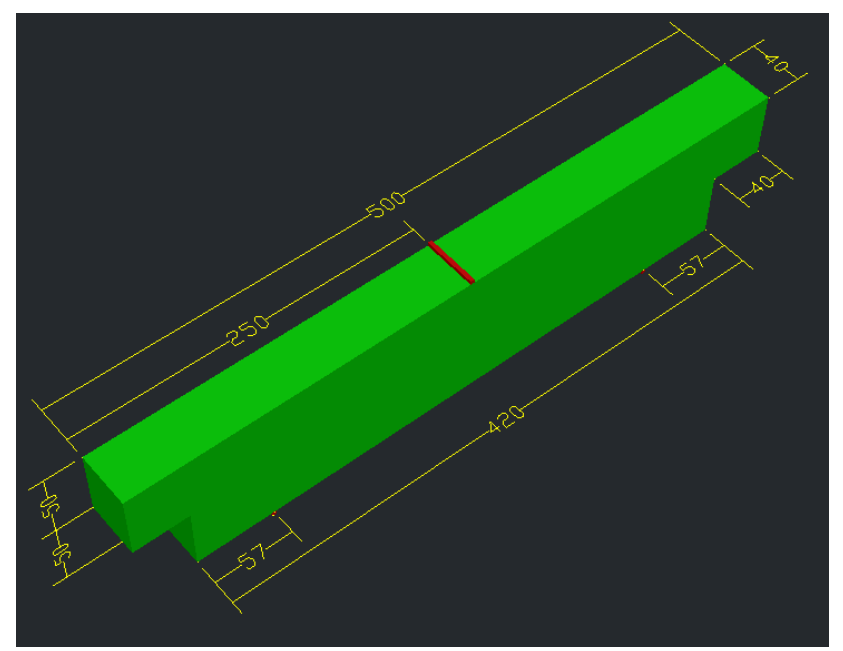

Figure $13 \mathrm{D}$ view of the concrete beam model

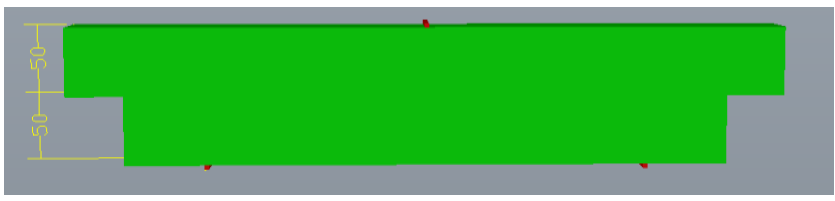

Figure 2 Front view of the concrete beam model

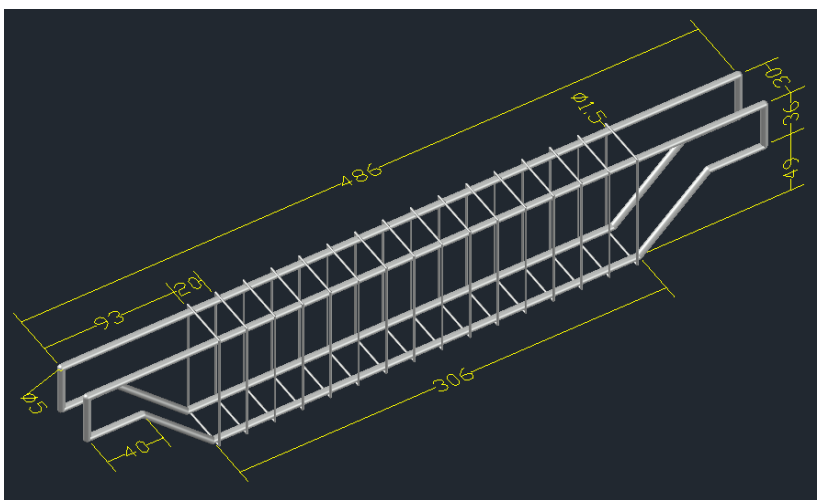

Figure $33 \mathrm{D}$ View of the reinforcing steel inside the concrete beam model

\subsection{Simulation Setup}

Figure 4 shows the work flow of the IBS RC beam simulation. The 3D modelling works were done using AutoCAD software. 3D models such as concrete beam, main reinforcement, spiral shear links, connections, and steel anchor plates were drawn before exporting the 3D model into .IGES data file. The .IGES data file was then imported into Autodesk 
simulation mechanical for finite element analysis. The 3D model also required that mesh size, material parameters, constraint, and applied loads before simulation be defined. Detail analysis selection and input parameters are discussed in following section. After the simulation, correct and sound results were extracted for comparison and discussion. Results with errors such as too much distorted element or missing element may need to repeat the simulation starting from the checking of 3D model from AutoCAD.

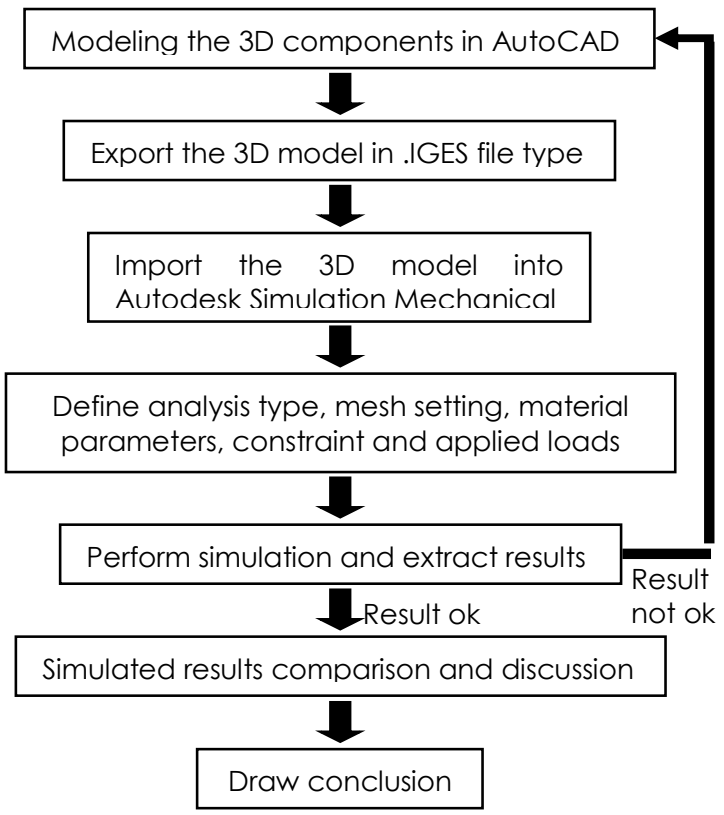

Figure 4 Modelling flow chart for IBS RC Beam

A new project is created by running the Autodesk Simulation Mechanical with the AutoCAD drawing (.IGES file type) of the precast IBS RC beam as shown in Figure 5. The model is based on MES with Nonlinear Material Models analysis type. Unit system is based on the Système international d'unités (SI units) with the exception of length which is in millimetre.

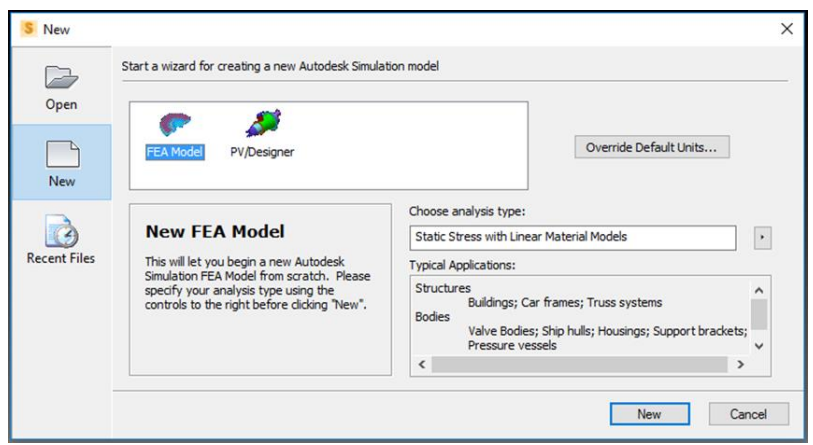

Figure 5 Creating a new Autodesk Simulation model

The model is ready to have mesh generated, and by default, the element type will be automatically set to brick [9]. A "Generate 3D Mesh" button can be found under the "Mesh" ribbon tab. Mesh size selected for this model is of the average or intermediate size, as shown in Figure 6. A "Meshing Results" should indicate that all parts have been meshed successfully. Nodes in a brick element type of mesh can be seen at the surface of the model as shown in Figure 7.

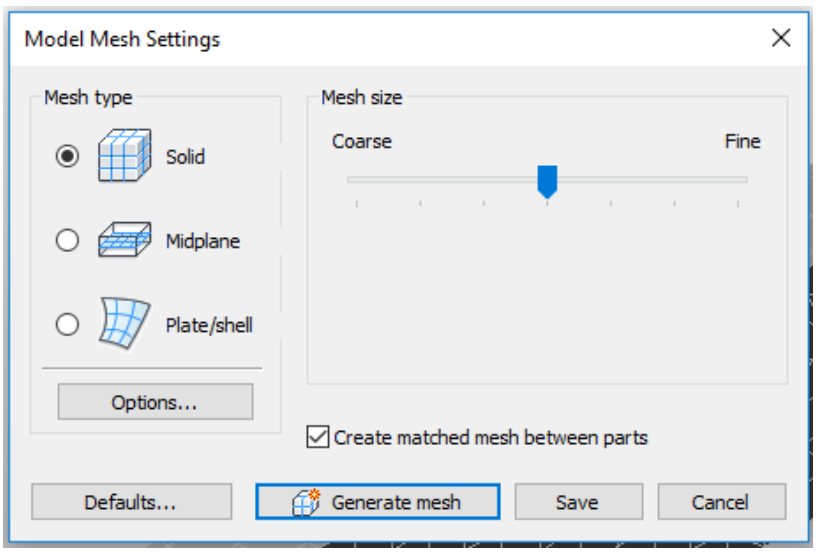

Figure 6 Mesh size selection

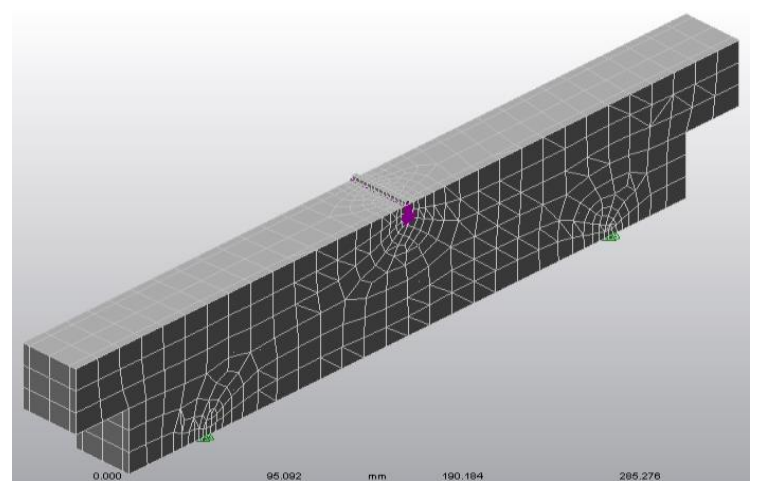

Figure 7 Mesh on the model

After selecting the surface of the model by clicking the face of the load-applying part, a "Prescribed Displacement" command, which can be found under "Setup" ribbon tab, can be used to apply displacement to the surface, given the magnitude (in $\mathrm{mm}$ ) and direction as shown in Figure 8. The $-6.5 \mathrm{~mm}$ of prescribed displacement magnitude was used for this model as the value was taken from the ultimate stage of flexural test experimental counterpart. The negative value of the magnitude indicates that the displacement is moving in a negative Z-direction relative to the model.

Constraints define how the FEA was tied down in space. If a part of the model is tied down, the part can neither translate nor rotate, the part was fully constrained [10]. "General Constraint" menu can be found under the "Setup" ribbon tab. The "Predefined Fixed" constrained button is applied to the surface of the supports in contact with the model. By doing so, 
the "Constrained DOFs" section for all six checkboxes had to be selected. In other words, the nodes of the surface of the support part were fully constrained.

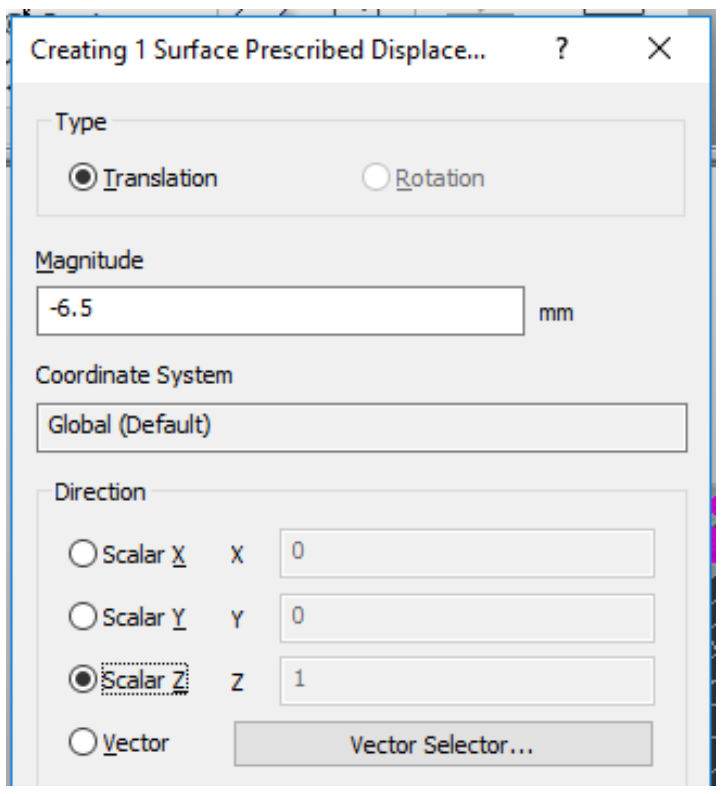

Figure 8 Surface prescribed displacement input box

Parameters such as the name of parts and their subsequent element types, and materials used were defined by selecting the red-highlighted section in the FEA Editor as shown in Figure 9. For this IBS RC beam model, all element types were set to brick type by default, and the element definition was set to von Mises (VM) Curve with Isotropic Hardening for concrete beam part, VM with Kinematic Hardening for the reinforcing steel, and Elastic Isotropic for the load-applying block, and also the support blocks.

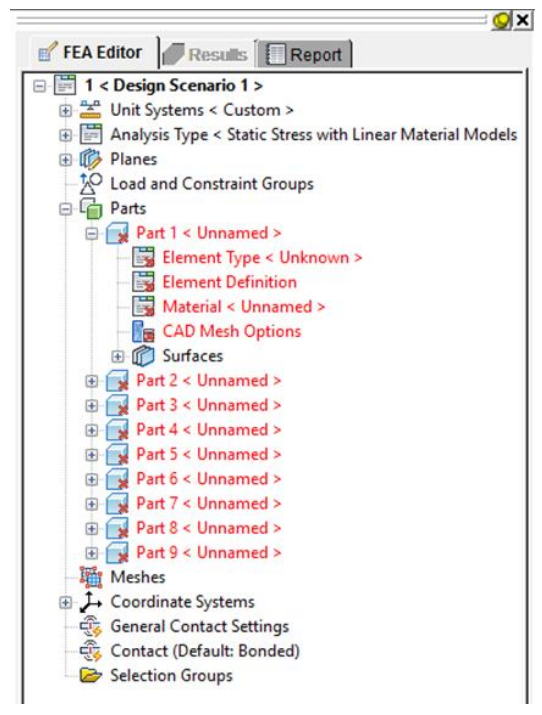

Figure 9 FEA Editor before inputting the parameters
Material type such as Reinforcing Steel (Medium/High Strength) or Concrete (Medium Strength) was selected accordingly based on the parts of the model. Naturally, beam in the model was defined as concrete; while the reinforcement bar and shear links were defined under reinforcing steel. However, the specification for the said materials such as the modulus of elasticity or yield strength, given in default by the material library was inaccurate when compared to the experimental counterpart; hence the specification values needed to be rectified in respect to the laboratory tests value in Tables 1-3. Figure 10 shows the example of element material specification input box.

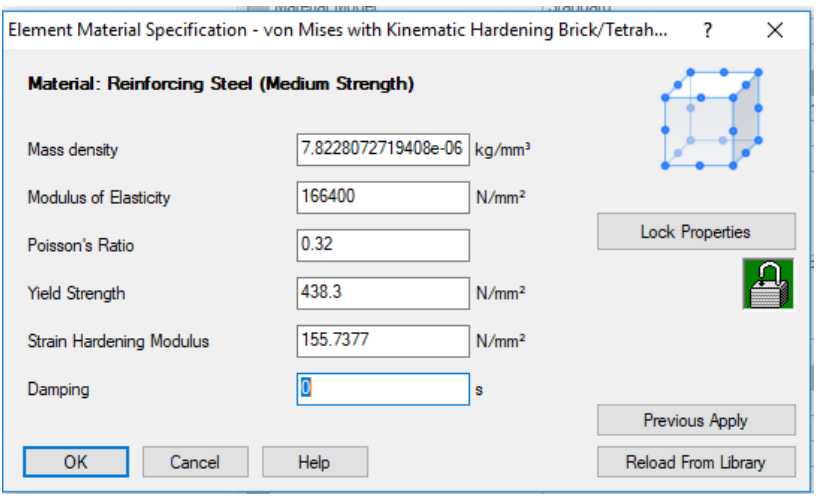

Figure 10 Element material specification input box

For the load-applying block and also the support block, since the blocks were not part of the specimen nor important in determining the modulus of rupture of the beam, elastic isotropic properties were provided with a significantly high modulus of elasticity, in this case, is $500000 \mathrm{~N} / \mathrm{mm}^{2}$. This is to prevent any deformation of the blocks during simulation, and to provide uniform displacement for the load-applying block [11]. After all the constraints and displacement were set to the model according to the experimental specifications, the simulation was started. The simulation started with Sim-Mech analysis under the analysis ribbon tab.

\subsection{RESULTS AND DISCUSSION}

The deflection and cracking behaviour of reinforced concrete beam under flexural test mainly relied upon the modulus of rupture (MOR) or the flexural tensile strength of the concrete and other factors. Factors such as strength levels, aggregate characteristics, moisture content of the specimen, specimen geometry, compaction and curing conditions, admixtures types, and concrete age played an important part in determining the MOR, and the flexural feature of the concrete [12]. 


\subsection{Beam Deflection}

A stress versus time-step graph of the IBS RC beam is illustrated in Figure 11. The time-step value ended at 1 second, indicating that the model reached a displacement of $6.5 \mathrm{~mm}$ at 1 second due to the prescribed displacement parameter defined in the FEA Editor.

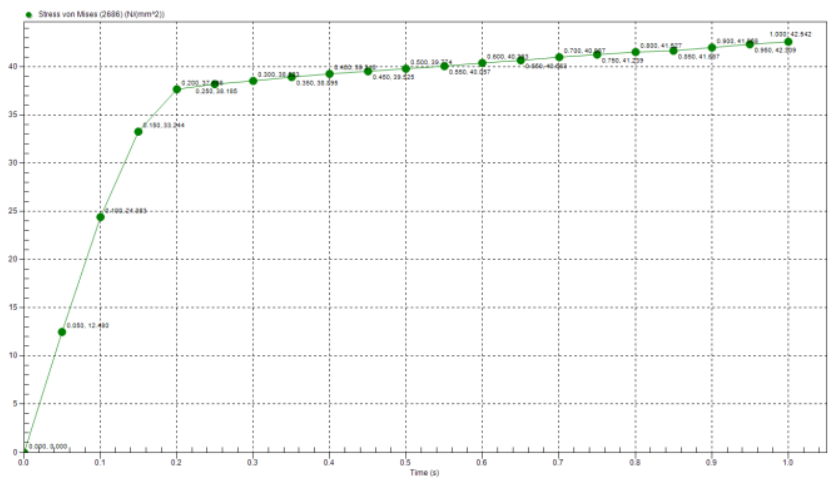

Figure 11 Von Mises stress versus Time-Step graph of IBS RC Beam

Table 4 shows data of the displacement and corresponding load for five different IBS RC beam specimens under flexural test, which were obtained from the experimental study conducted beforehand. The average yield displacement and load were about $1.46 \mathrm{~mm}$, and $31 \mathrm{kN}$, respectively, while the ultimate displacement and ultimate load were about $6.34 \mathrm{~mm}$ and $38.60 \mathrm{kN}$, respectively.

Table 4 Load-displacement experimental data

\begin{tabular}{ccccc}
\hline $\begin{array}{c}\text { Specimen } \\
\text { Number }\end{array}$ & $\begin{array}{c}\text { Yield } \\
\text { Load } \\
(\mathbf{k N})\end{array}$ & $\begin{array}{c}\text { Yield } \\
\text { Displace } \\
\text { ment } \\
\mathbf{( m m )}\end{array}$ & $\begin{array}{c}\text { Ultimate } \\
\text { Load } \\
\mathbf{( k N )}\end{array}$ & $\begin{array}{c}\text { Ultimate } \\
\text { Displace } \\
\text { ment } \\
\mathbf{( m m}\end{array}$ \\
\hline 1 & 29.00 & 1.40 & 34.00 & 5.40 \\
2 & 33.00 & 1.40 & 36.00 & 4.50 \\
3 & 35.00 & 1.50 & 42.00 & 5.60 \\
4 & 29.00 & 1.50 & 40.00 & 8.00 \\
5 & 29.00 & 1.50 & 41.00 & 8.20 \\
\hline Average & 31.00 & 1.46 & 38.60 & 6.34 \\
\hline
\end{tabular}

The experimental data in Table 4 was then compared with the simulated nonlinear analysis data in Figure 11. Both results were plotted in a loaddisplacement idealized bilinear curve as shown in Figure 12.

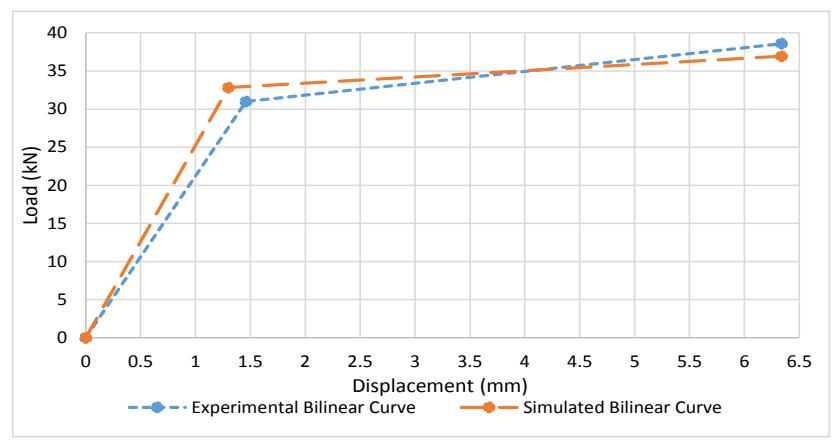

Figure 12 Load-displacement curve for both simulation and experimental data

Based on Figure 12, the comparison between the simulation and experimental data in terms of percentage accuracy in load and displacement is shown in Table 5 . The yield load of the IBS RC beam was $32.82 \mathrm{kN}$ based on the nonlinear finite element analysis. Meanwhile, the experimental counterpart produced $31.00 \mathrm{kN}$ of yield load. The accuracy of the yield load was about $94.12 \%$. It should be noted that the simulation computation showed that the beam yield was at $1.30 \mathrm{~mm}$ in displacement, as opposed to the experimental which was $1.46 \mathrm{~mm}$ of displacement, hence having an accuracy of $89.04 \%$. The elastic gradient line before the yield point was reached for both the simulation and experimental data had an accuracy of $81.08 \%$.

For ultimate displacement as shown in Table 6, most of the FEA software was not able to find the stopping point of the analysis, or in other words when the structure failed or ruptured unless boundary condition was stated beforehand. In this paper, an ultimate displacement was set to $6.5 \mathrm{~mm}$ of displacement over a total of one second of timestep. By interpolation to $6.34 \mathrm{~mm}$ of displacement following the experimental counterpart, the result showed that the ultimate load was then approximately $36.97 \mathrm{kN}$ compared to the experimental which was $38.60 \mathrm{kN}$. The accuracy at $6.34 \mathrm{~mm}$ for both ultimate loads was $95.79 \%$. The plastic gradient before ultimate, however, only had an accuracy of $52.86 \%$. This was due to the homogeneous material properties in finite element simulation that all the material behaviours are in perfect condition without honeycombs or voids. 
Table 5 Accuracy percentage between FEA and experimental data for yield point

\begin{tabular}{|c|c|c|c|}
\hline & $\begin{array}{c}\text { Yield } \\
\text { Displacem- } \\
\text { ent }(\mathrm{mm})\end{array}$ & $\begin{array}{l}\text { Yield Load } \\
\quad(\mathrm{kN})\end{array}$ & $\begin{array}{c}\text { Gradient } \\
\text { before yield, } \\
\text { Dyield }\end{array}$ \\
\hline $\begin{array}{l}\text { Simulated } \\
\text { Nonlinear } \\
\text { Analysis }\end{array}$ & 1.30 & 32.82 & 25.25 \\
\hline $\begin{array}{c}\text { Experimental } \\
\text { Data }\end{array}$ & 1.46 & 31.00 & 21.23 \\
\hline $\begin{array}{c}\text { Accuracy } \\
\text { Percentage } \\
(\%)\end{array}$ & 89.04 & 94.12 & 81.08 \\
\hline
\end{tabular}

Table 6 Accuracy percentage between FEA and experimental data for ultimate point

\begin{tabular}{c|ccc}
\hline & $\begin{array}{c}\text { Ultimate } \\
\text { Displacem- } \\
\text { ent (mm) }\end{array}$ & $\begin{array}{c}\text { Ultimate } \\
\text { Load (kN) }\end{array}$ & $\begin{array}{c}\text { Gradient } \\
\text { before } \\
\text { ultimate, Vult }\end{array}$ \\
\hline $\begin{array}{c}\text { Nonlinear } \\
\text { Analysis } \\
\text { Experimental } \\
\text { Data }\end{array}$ & 6.34 & 36.97 & 0.82 \\
\hline $\begin{array}{c}\text { Accuracy } \\
\text { Percentage } \\
\text { (\%) }\end{array}$ & 6.34 & 38.60 & 1.56 \\
\hline
\end{tabular}

\subsection{Flexural Analysis of Beam and Crack Pattern}

Crack pattern of the IBS RC concrete beam from the beginning of the test until the end are presented in stages. These sub-sections discuss the critical stresses contour for the concrete beam and the reinforcing steel inside the beam model.

\subsubsection{Uncracked Concrete Stage}

When tensile stresses are less than the flexural strength, or MOR due to small loads, the whole cross section of the IBS RC beam defied bending, with tension on one side of the beam and compression on the other [13]. As long as the moment is small enough, the beam did not induce cracking, the strains across the beam cross section were also small, and the neutral axis was at the centroid of the cross section [14]. As shown in Figure 13, the arrow indicates the areas where the initial VM stress took place on the concrete model. The initial stress came from the applied load block above the model, and also the reaction forces at the supports. Figure 14 shows the condition of the reinforcing steel inside the model. The arrow above the model shows that the reinforcing steel received some of the load applied, while the bottom arrows show that the area received little to no stress due to the fixed support provided. Figure 15 shows the laboratory experiment done at the uncracked concrete stage. The arrows indicate the position of the applied load and two supports at the beginning of the test.

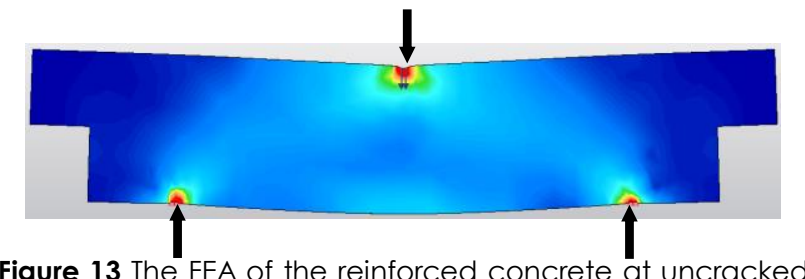

Figure 13 The FEA of the reinforced concrete at uncracked concrete stage

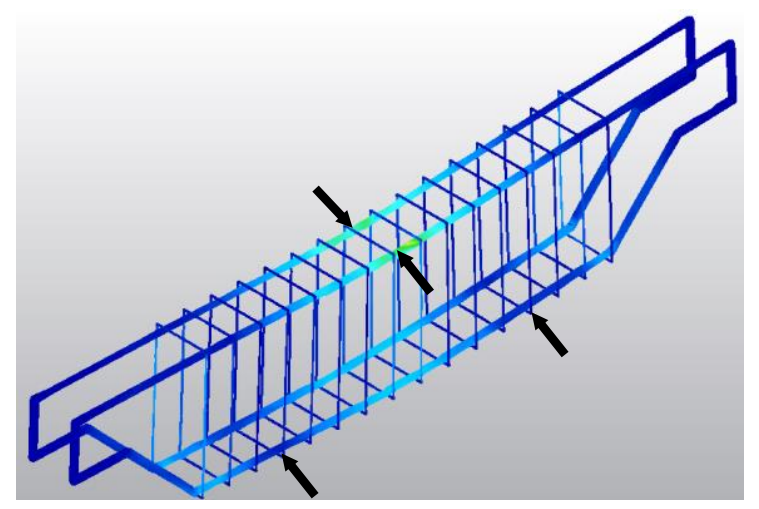

Figure 14 The FEA of the reinforcing steel inside at uncracked concrete stage

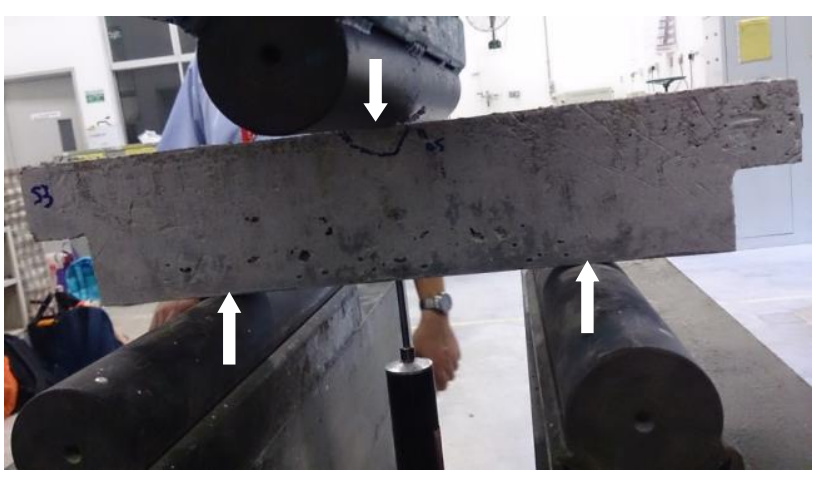

Figure 15 Laboratory test at uncracked concrete stage

\subsubsection{Cracked Concrete-elastic Stresses Stage}

In a well-designed beam with proper concrete mix, flexural cracks or so-called "hairline" cracks are fine cracks that are almost invisible to the everyday observers. As loads progressively increased above the cracking load, the number of cracks multiplied, and the width also increased too. If the loads were further increased, crack widths will get wider, although the number of cracks was more or less the same [15]. Generally, to control cracking, instead of using a minimum amount of large reinforcing bar size to fulfil the required area of steel, $A_{s}$, large quantity of smaller-diameter bars are preferred, so that the bars will be well distributed over the tensile zone of the concrete [16].

If the load increases beyond the flexural strength limit of the concrete, cracks will begin to form at the bottom of the beam. When the extreme tensile fibre, 
$f_{c r}$ is the same as the value of MOR, the moment at which the cracks begin to develop at the bottom of the beam is called the cracking moment, $M_{c r}$ [13]. At this stage, maximum strains were still considerably low in concrete in both tension and compression.

After the bottom of the beam has cracked due to failure to resist tensile stresses, or in other words the resistance is taken cared by the reinforcing steel [17]. In the tension zone, a sudden transfer of tension force to the reinforcements from the concrete caused an increase of strain in the reinforcements. Subramanian [14] recommended at least a minimal amount of tensile reinforcement should be provided to prevent sudden failure of the beam. The said stage continues as long as the compression stress at the top of the beam is less than one-half of the precast concrete's compression strength, $\mathrm{f}^{\prime} \mathrm{c}$ and the steel stress is less than yield stress [13].

Figure 16 shows the cracked-concrete elastic stresses stage, when the IBS RC beam began to show a pattern of the VM stress that propagated upward from the bottom of the model. The behaviour of such pattern is primarily due to the bending moment of the beam is greater than the cracking bending moment, hence unable to resist the tensile stresses. The beam then suffered from a series of ascending cracks called the flexural crack. As can be seen in Figure 17, the VM stress contour grew larger in area, and more intense in colour. The two arrows show where the shear cracks began to develop, in addition to the flexural cracks. Shear cracks formed at the bottom, close to the supports and propagated upwards, inclined to the beam axis. If a heavier load is applied, both types of cracks may grow larger in width.

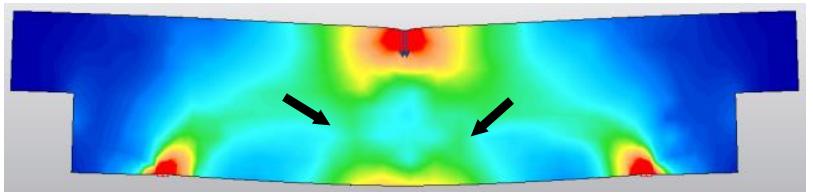

Figure 16 The FEA of the reinforced concrete at crackedconcrete elastic stresses stage

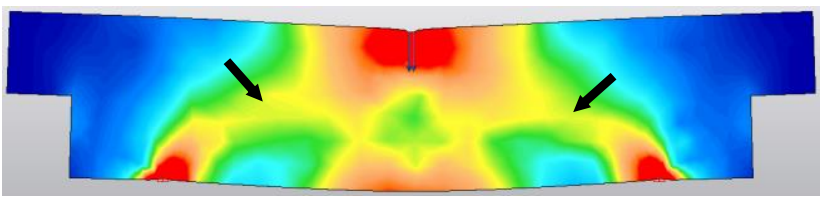

Figure 17 The FEA of the reinforced concrete at further cracked-concrete elastic stresses stage

Figure 18 shows the reinforcing steel inside of the model where the arrow indicates that some of the tensile stresses are being transferred from the concrete into the steel. Figure 19 shows the laboratory work that displayed shear cracks, in addition to flexural cracks on the reinforced concrete specimen due to stress concentration. Through the simulation, user could observe the stress concentration of the IBS RC beam. Hence the simulation can be tied to the actual experimental test for data analysis, and failure behaviour for discussion.

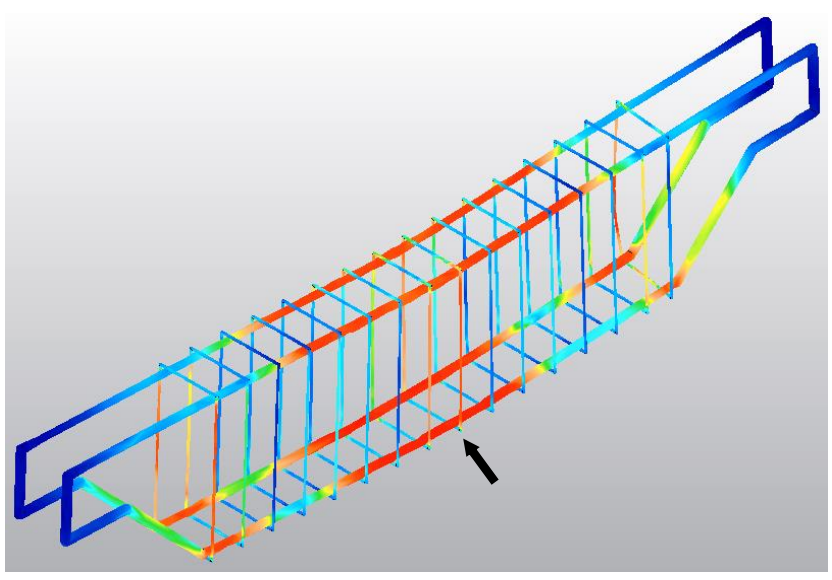

Figure 18 The FEA of the reinforcing steel inside at further cracked-concrete elastic stresses stage

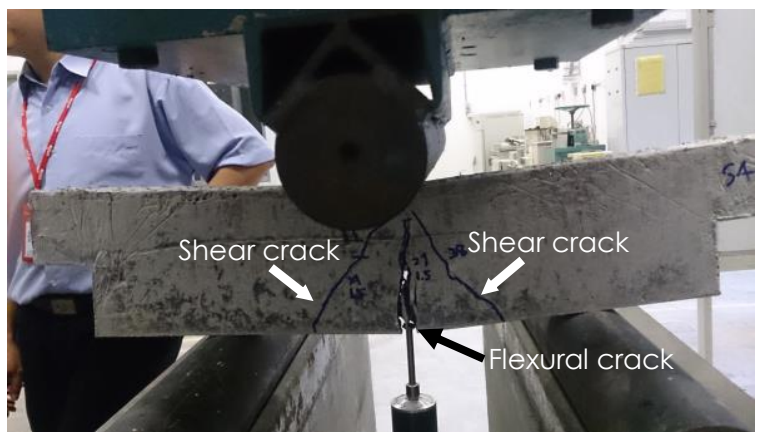

Figure 19 Laboratory test at further cracked-concrete elastic stresses stage

\subsubsection{Yielding of Tension Reinforcement - Ultimate Strength Stage}

When the load was applied further so that the compressive stresses were greater than one-half of the concrete's compression strength f'c, the neutral axis moved further upward, and so did the tensile crack [18]. The tensile stress in the reinforcement and the compression stress in the concrete beam also increased. The concrete compression stresses began to shift noticeably from a straight line to a non-linear line. However, over the beam cross section, strain distribution was still in a linear manner [19].

As can be seen in Figure 20, the top arrow indicates a relatively high compression VM stress at the top of the IBS RC beam. If the load applied is increased further, compression stress in the concrete and the tensile stress in the reinforcing steel will be greater as well. By checking the progression of VM stress against time-step graph of the simulation for 
both the concrete and the reinforcing steel parts, the starting of the yield point was detected. The said yield point began at the bottom of the reinforcing steel, as shown by the arrow in Figure 21, and as anticipated in flexural test done earlier, and is shown in Figure 22. The model can now be classified as an under-reinforced beam due to the yielding of steel that occurred before the crushing of concrete. Under-reinforced beam in general caused a ductile or gradual failure which gives a clear warning prior to the failure, as opposed to the brittle or sudden failure of over-reinforced beam. Figures 20 and 22 show the compression zone on top of the concrete part of the model, where a greater stress can be seen as it approached the ultimate stage. This then led to greater cracks and crushing of concrete, which led to the eventual collapse of the beam.

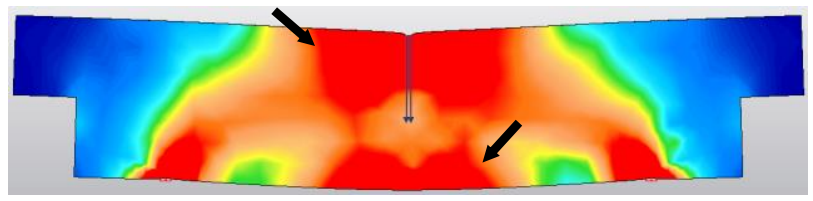

Figure $\mathbf{2 0}$ The FEA of the reinforced concrete at ultimate strength stage

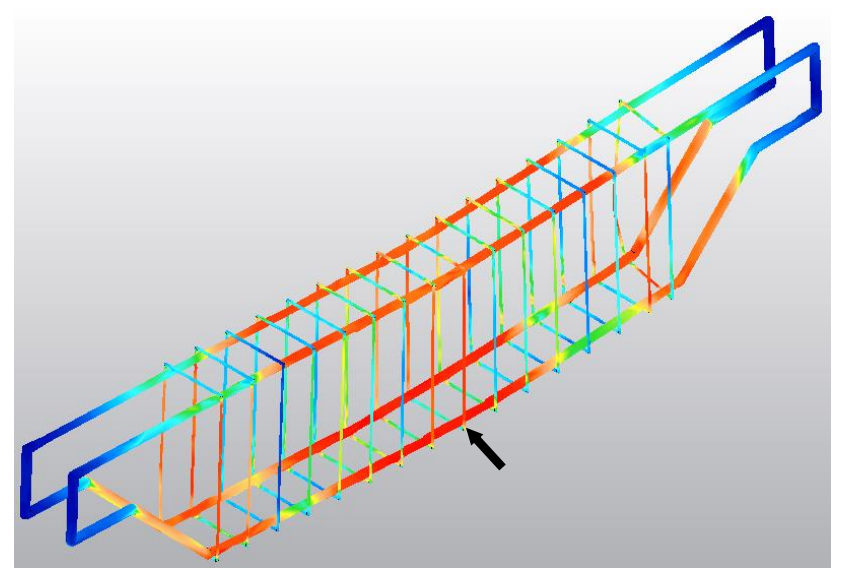

Figure 21 The FEA of the reinforcing steel at ultimate strength stage

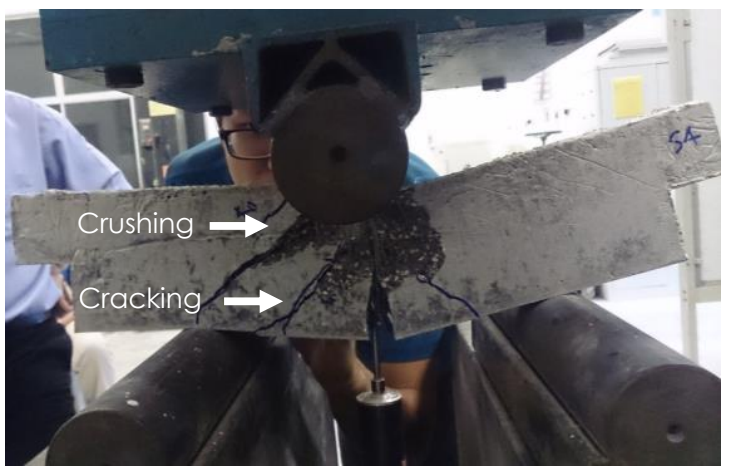

Figure 22 Laboratory test at ultimate strength stage
The IBS RC beams have both tension and compression steel reinforcement. The beam depends on the area of tension steel provided to give an increase in moment-resisting capacity. Besides, by including compression steel in the beam, the mode of failure may change from failing due to compression in concrete to tension failure of steel. Besides steel, factors such as resisting moment and the amount of curvature that the beam can endure before any flexural failure, can also be increased [14]. The beam also underwent shrinkage and creep in a long-term deflection; having compression steel effectively reduced such effect [20]. A special IBS RC beam can be customised based on the structural usage and desired capacity [21]. For instance the IBS beam block in Yip and Marsono's [22] study can be customised for residential structures with other compatible composite structural joint systems. Other than that, this IBS beam component can be installed to the column invented by Yip et al. [23] easily with bolt and nuts as joint. Therefore, this beam capacity simulation and studies are vital for the real industry application in developing of the IBS in Malaysia.

\subsection{CONCLUSION}

In conclusion, the FEA when compared to its actual experiment counterpart exhibited the same behaviour of beam deflection, flexural analysis on beam, and crack pattern. In beam deflection, a comparison of data results between the FEA and laboratory test results, found that yield displacement and yield load had an accuracy of $89.04 \%$ and $94.12 \%$, respectively, whereas ultimate load had an accuracy of $95.79 \%$. The line gradient accuracy prior to yield point for both simulation and experimental was $81.08 \%$. However, the line gradient between the ultimate point and the yield point for both simulation and experimental was only $52.86 \%$. Flexural analysis of IBS RC beam shown in the FEA exhibited the same crack and failure pattern as in the experimental part. At the uncracked concrete stage, the VM stresses started to develop at the top of the beam due to the load applied, and also at the two supports at the bottom of the beam due to reaction forces. Results in the FEA showed that the reinforcing steel started to receive some tension stress at the bottom steel. At the cracked concrete-elastic stresses stage in simulation and experimental part, flexural cracks propagated upwards from the base of the beam as the moment in the beam exceeded the cracking moment. Besides flexural cracks, shear cracks began to develop near the supports and advanced upwards, inclined to the beam axis. As a stronger load was applied, yielding of tension reinforcement can be seen, followed by crushing of concrete due to compressive stresses, and this eventually led to the collapse of the beam. 


\section{Acknowledgement}

The authors would like to express gratitude to Universiti Tunku Abdul Rahman and its facilities. Elastic Infills, Beams and Column for Natural Disaster Resistance House. MyIPO. Patent No UL.2016700916.

\section{References}

[1] Gan, Y., Shen, L., Chen, J., Tam, V., Tan, Y., and Illankoon, I. 2017. Critical Factors Affecting the Quality of Industrialized Building System Projects in China. Sustainability. 9(2): 216.

DOI: http://dx.doi.org/10.3390/su9020216.

[2] Megally, S., Seible, F., Garg, M., and Dowell, R. 2002. Seismic Performance of Precast Segmental Bridge Superstructures with Internally Bonded Prestressing Tendons. PCl Journal. 47(2): 2-18.

DOI: http://dx.doi.org/10.15554/pcij.03012002.40.56.

[3] Thanoon, W., Lee, W., Mohd, R., Mohd, S., and Mohd, S. 2013. The Experiences of Malaysia and other countries in industrialised building system. International Conference on Industrialised Building Systems. Serdang: Universiti Putra Malaysia. 10-11.

[4] Jayaram, M. 2007. Mechanics of Materials with Programs in C. 1st ed. New Delhi: Prentice-Hall of India.

[5] Rao, D. 2011. Strength of Materials. 1st ed. Hyderbad: Universities Press (India). 174-175.

[6] Barkanov, E. 2001. Introduction to the Finite Element Method. 1st ed. Riga, Latvia: Riga Technical University. 5-6.

[7] Logan, D. and Chaudhry, K. 2007. A First Course in the Finite Element Method. 4th ed. Thomson Canada: Thomson Canada Limited. 1-2.

[8] Moaveni, S. 2001. Finite Element Analysis. 1st ed. Upper Saddle River, N.J.: Prentice Hall. 1-3.

[9] Autodesk. 2017. von Mises Material Properties. [online] Autodesk Simulation Mechanical. Available at: http://help.autodesk.com/view/ASMECH/2017/ENU/? guid $=$ GUID-3BDBFBCD-6870-4428-BBB 1-461FDAAF7969.

[10] Autodesk. 2011. Autodesk Simulation Mechanical 2012 Part 1 - Seminar Notes. 1st ed. San Rafael: Autodesk, Inc. 7-25.
[11] Arivalagan, S. and Kandasamy, S. 2010. Finite Element Analysis on the Flexural Behaviour of Concrete Filled Steel Tube Beams. Journal of Theoretical and Applied Mechanics. 2(48):1-4.

[12] Ahmed, M., Mallick, J. and Abul Hasan, M. 2016. A Study of Factors Affecting the Flexural Tensile Strength of Concrete. Journal of King Saud University - Engineering Sciences. 28(2). DOI: http://dx.doi.org/ 10.1016/j.jksues.2014.04.001.

[13] McCormac, J. and Brown, R. 2016. Design of Reinforced Concrete. 2nd ed. Hoboken, N.J: Wiley.

[14] Subramanian, N. 2014. Design of Reinforced Concrete Structures. 1st ed. Oxford, UK: Oxford University Press. 143, $145,163$.

[15] Nilson, A., Darwin, D. and Dolan, C. 1991. Design of Concrete Structures. 13th ed. New York, NY: McGraw-HIII.

[16] Broms, C. 2005. Concrete Flat Slabs and Footings: Design Method for Punching and Detailing for Ductility. Ph.D. Royal Institute of Technology.

[17] Williams, A. 2004. Design of Reinforced Concrete Structures. 1st ed. Chicago, IL: Dearborn Real Estate Education.

[18] Punmia, B., Jain, A. and Jain, A. 2007. Limit State Design of Reinforced Concrete. 1st ed. New Delhi: Laxmi Publications.

[19] Chamis, C. 1975. Structural Design and Analysis: Composite Materials. 7th ed. New York: Academic Press.

[20] Washa, G. and Fluck, P. 1952. Effect of Compressive Reinforcement on the Plastic Flow of Reinforced Concrete Beams. ACl Journal Proceedings. 49(10). DOI : http://dx.doi.org/10.14359/11806.

[21] Yip, C.-C., Marsono, A. K., Wong, J. Y., and Amran, M. Y. H. 2015. Flexural Strength of Special Reinforced Lightweight Concrete Beam for Industrialised Building System (IBS), Journal of Science \& Engineering, Jurnal Teknologi. 77(1): 187-196. DOI: https://doi.org/10.11113/jt.v77.3505.

[22] Yip, C.-C., and Marsono, A. K. 2016. Structural Seismic Performance of Reinforced Concrete Block System for Two Storeys Safe House. Journal of Science \& Engineering, Jurnal Teknologi. 78(2): 83-97. DOI: https://doi.org/10.11113/jt.v78.5098.

[23] Yip, C.-C., Marsono, A. K., Wong, J. Y., and Lee, S. C. 2018. Seismic Performance of Scaled IBS Block Column for Static Nonlinear Monotonic Pushover Experimental Analysis. Journal of Science \& Engineering, Jurnal Teknologi. 80(1): 89-106. DOI: https://doi.org/10.11113/jt.v80.10799. 